\title{
Amorfrutins: A Promising Class of Natural Products that Are Beneficial to Health
}

\author{
Sascha Sauer*[a]
}

The incidence of complex noncommunicable diseases has strongly increased over the last several decades in the US, Europe and other parts of the world that have adopted a western lifestyle (M. Ezzati, E. Riboli, Science 2012, 337, 1482-1487; S. Smyth, A. Heron, Nat. Med. 2006, 12, 75). Despite considerable investment in the development of new types of drugs, options for the treatment of many common diseases remain inadequate. If current trends prevail, the rising incidence of disorders such as obesity and type 2 diabetes mellitus (T2DM) will soon result in an unsustainable burden on society (World
Health Organization Technical Report Series 2000, 894, i-xii, 1 253). Given the difficulty of treating fully developed complex disorders, new strategies for early intervention and prevention of common diseases are of great interest. Dietary natural products with beneficial effects, such as the recently described antidiabetic and lipid-lowering amorfrutins, could pave the way for efficiently treating and preventing metabolic and other complex diseases (C. Weidner, et al. Proc. Natl. Acad. Sci. USA 2012, 109, 7257-7262).

\section{Amorfrutins}

Amorfrutins represent a largely unexplored class of natural products that were first found in, and consequently named after, the bastard indigobush Amorpha fruticosa. ${ }^{[1]}$ The exact definition of these natural products remains vague. In general, amorfrutins feature a simple planar 2-hydroxybenzoic acid core structure, usually decorated with isoprenoid side chains $\left(R^{1}\right)$, and aromatic or alkyl side chains $\left(\mathrm{R}^{4}\right.$; Figure $\left.1 \mathrm{C}\right) .^{[2]}$ Typically, they also exhibit a methoxy or a hydroxyl group at position 4. A. fruticosa originates from North America, Korea and China, but is also found in other regions, such as around the Mediterranean. The first amorfrutins (amorfrutins $A$ and $B$ ) were isolated from ethanolic extracts of the stems, leaves and powdered fruits of $A$. fruticos $a^{[1]}$ Interestingly, the fruits of this plant can be used for producing condiments.

However, amorfrutins can also be efficiently extracted from the edible roots of the liquorice species Glycyrrhiza foetida, which contains (amongst other compounds) several grams of amorfrutin A and amorfrutin 2 (Figure 1C) per kilogram of plant material. ${ }^{[2,3]} \mathrm{G}$. foetida is a small bush, which is common in the south of Spain and in northwest Africa. The two Glycyrrhiza species, G. foetida and the well-known, more commonly used Glycyrrhiza glabra, are very similar but vary in their flowering and fruiting states. Because of their similarity, the same Arabic name ("arq as-sus") is used for both species (Karsten Siems, personal communication)..$^{[4]}$

These species seem to contain largely different compounds; this could explain why $G$ glabra tastes less bitter than $G$. foeti$d a{ }^{[5]}$ While G. glabra is widely used for manufacturing tea, licorice candies and other products in many countries, in north-

[a] Dr. S. Sauer

Otto-Warburg Laboratory, Max Planck Institute for Molecular Genetics

Ihnestrasse 73, 14195 Berlin

E-mail: sauer@molgen.mpg.de

Homepage: http://www.molgen.mpg.de/nutrigenomics west Africa, G. foetida and G. glabra are traditionally used to produce edible flavours and to treat pulmonary diseases. ${ }^{[4]}$ Furthermore, like many natural products the amorfrutins exhibit antimicrobial activities, ${ }^{[1]}$ with some specificity for Gram-positive and acid-fast microorganisms. Evidence for anti-inflammatory properties of amorfrutin A has also been reported. ${ }^{[5]}$

Surprisingly, it was recently shown that various amorfrutins can potently counteract major metabolic disorders in vivo, such as insulin resistance and liver steatosis. ${ }^{[2,3,6]}$ These beneficial effects arise, at least in part, from selective activation of nuclear receptor peroxisome proliferator-activated receptor gamma (PPAR $\gamma$ ).

\section{Interaction of Amorfrutins with the Nuclear Receptor PPAR $\gamma$}

Nuclear receptors such as PPAR $\gamma$ are ligand-activated transcription factors that bind to more-or-less specific sequences of the genome and thereby control gene expression (Figure 2). ${ }^{[7]}$ Thus, nuclear receptors are attractive targets for drug development.

PPAR $\gamma$ is a key regulator of genes for fatty acid and glucose metabolism. Additionally, PPAR $\gamma$ can repress the expression of genes involved in the inflammatory response by interacting (in partly still poorly understood ways) with transcription factors such as NF-KB (nuclear factor kappa-light-chain-enhancer of activated B-cells). ${ }^{[8]}$ Consequently, PPAR $\gamma$ has been recognised as an important target for impeding the age-related decline of metabolism, and for potentially inhibiting inflammation and cancer. ${ }^{[9,10]}$ This nuclear receptor is expressed particularly in adipocytes (fat cells), macrophages (immune cells) and colon epithelial cells, but has also been detected in cells from various tissues including the brain. ${ }^{[11]}$ Two main isoforms of PPAR $\gamma$ have been found in human and mouse cells: the shorter ver- 


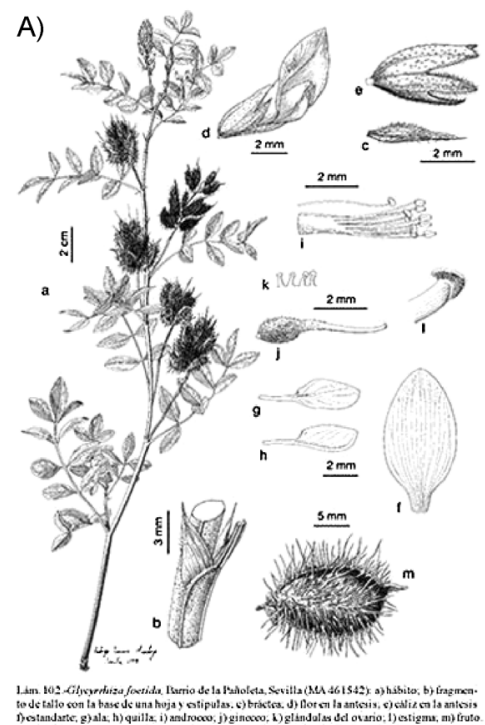

B)

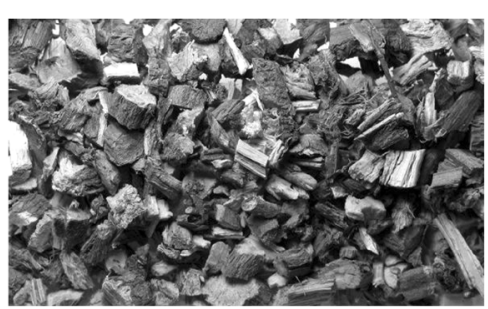

C)
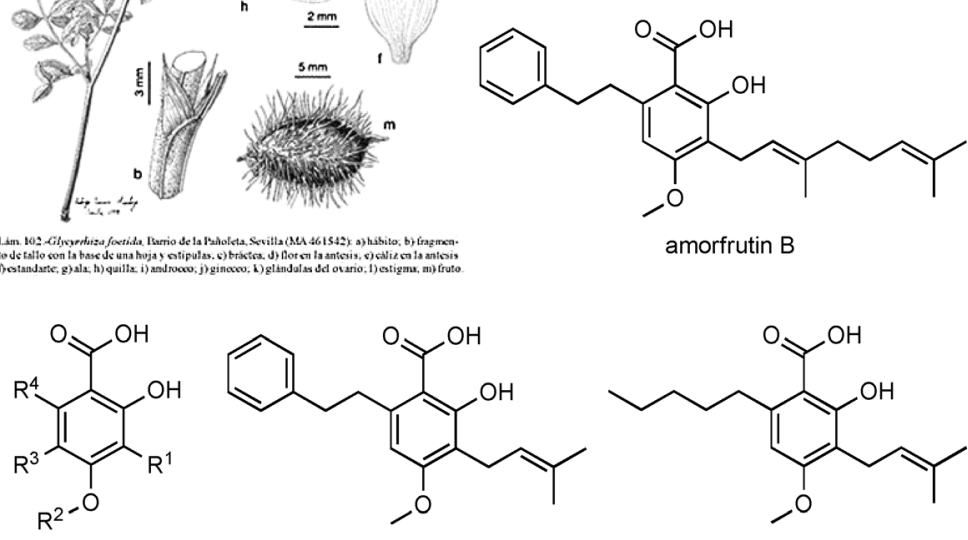

amorfrutin core structure

amorfrutin $\mathrm{A}$

Figure 1. Source and structures of amorfrutins. A) Many amorfrutins were isolated from liquorice species such as G. foetida, which was first described in 1799 (original excerpt from the Spanish journal: Fl. Atlant. 1799, 2, 170, Tab. 199). Amorfrutins can particularly be obtained from the edible roots of liquorice (B), or various parts of the shrub A. fruticosa such as the fruits. C) Amorfrutins exhibit similarities to salicylates: the core isoprenoid 2-hydroxybenzoic acid structure and various naturally occurring derivatives of the amorfrutins are shown.

sion (PPAR $\gamma 1$ ) is expressed in nearly all tissue types except muscle, whereas the slightly longer version (PPAR 2 2) is most abundant in adipose tissue and the intestine. ${ }^{[10 b, 12]}$

Because of its large $\left(1300 \AA^{3}\right)$ Y-shaped ligand-binding pocket, the ligand binding domain (LBD) of PPAR $\gamma$ interacts at micromolar affinity with a large variety of structurally diverse molecules, including those derived from food, such as lipids (Figure 2). Thereby, PPAR $\gamma$ can, amongst others, upregulate the genes required for lipid and glucose uptake. ${ }^{[13]}$ Notably, through interaction with PPAR $\gamma$, safe phytomedical chamomile or lemon balm extracts, which contain complex mixtures of natural products, have been shown to induce various metabolically beneficial effects in insulin-resistant obese mice. ${ }^{[14]}$

As reported recently, several amorfrutins bind specifically to the ligand-binding pocket of PPAR $\gamma$ with low-nanomolar to low-micromolar affinities (Table 1). ${ }^{[2,3,15]}$ Amorfrutins also interact with two other isotypes of PPAR $\gamma, \operatorname{PPAR} \alpha$ and PPAR $\beta / \delta$, but with about 10- to 100-fold weaker, micromolar binding affinities to these evolutionarily closely related nuclear receptors. ${ }^{[2,3,15]}$

PPAR $\alpha$ is predominantly expressed in the liver but also in other tissues. PPAR $\alpha$ regulates fatty acid oxidation and lipoprotein metabolism, as well as gluconeogenesis and ketone body biosynthesis. ${ }^{[8]}$ PPAR $\beta / \delta$ is expressed ubiquitously, and mainly controls fatty acid oxidation and adaptive thermogenesis. ${ }^{[8]}$ Interestingly, simultaneous activation of the PPARs by a single compound has been proposed as a combined or even synergistic therapeutic approach to achieve beneficial physiological effects. ${ }^{[16]}$ In conclusion, amorfrutins can be considered as selective, partial pan-agonists of the PPARs with a clear bias (around 10- to 100-fold) toward binding of PPAR $\gamma$.

Binding of strong agonists of PPAR $\gamma$, such as rosiglitazone, occurs at helix 12 of the LBD. ${ }^{[17]} \mathrm{X}$-ray crystallography of amorfrutins $A, B$ and 2 and the LBD of PPAR $\gamma$ showed that the amorfrutins bind instead close to the ligand entry site (and helix 3 ) of PPAR $\gamma$ (Figure 3A). ${ }^{[2,15]}$

Remarkably, amorfrutin A forms electrostatic and hydrogen bonds at its carboxyl group with specific amino acid side chains of the LBD of PPAR $\gamma$ (arginine 288 and serine 342; Figure $3 \mathrm{~B}$ ). This might significantly increase the nanomolar binding efficiency of amorfrutins to PPAR $\gamma$ compared to similar natural products lacking a carboxyl group, such as amorphastilbol. ${ }^{[18]}$ Moreover, ortho-phenylethyl and metaprenyl residues further stabilise binding of amorfrutins to the LBD of PPAR $\gamma$ by van der Waals interactions. The longer geranyl group of amorfrutin $B$ (in place of the prenyl side chain of amorfrutin $A$ ) results

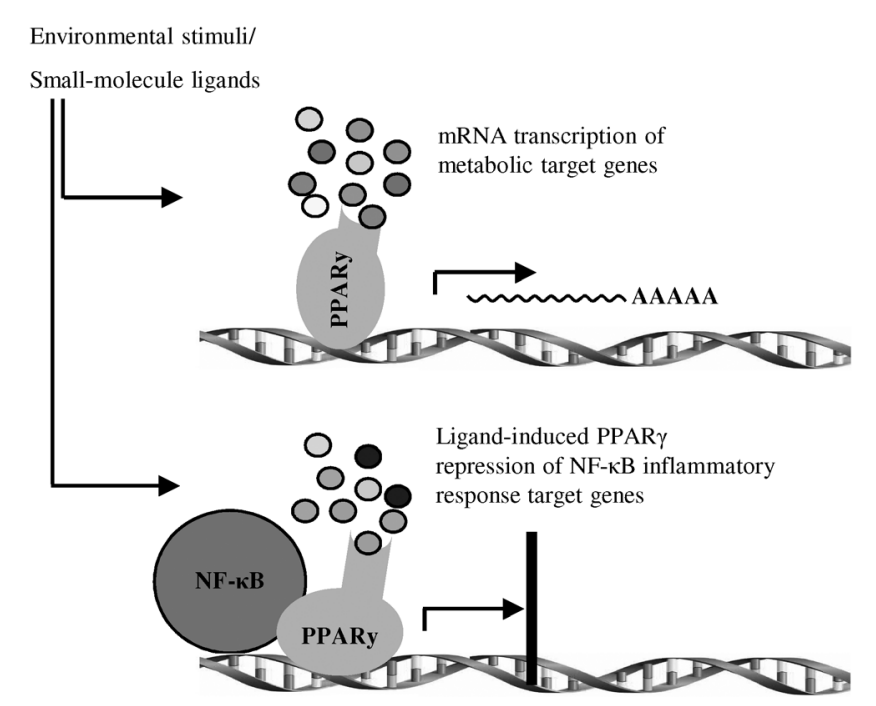

Figure 2. Ligand-based activation of PPAR $\gamma$ leading to more or less sequence-specific binding of genomic DNA. Depending on cellular stimuli mediated by various ligands (and many other regulatory proteins (not shown)) with PPAR $\gamma$, this nuclear receptor can upregulate the expression of genes involved in metabolism. Moreover, ligand-activated PPAR $\gamma$ can also bind to more-or-less specific sites of genomic DNA and thereby decrease the expression of genes induced by other transcriptional regulators, for example the important inflammation-triggering transcription factor NF- $\kappa \mathrm{B}$. However, PPAR $\gamma$ can also interfere with the NF-KB pathway by other mechanisms, for example by inducing degradation of the NF- $\kappa B / p 65$ complex, nuclear export of p65, or just competing for limiting amounts of shared co-activators with NF?B. ${ }^{[51]}$. N.B. Simplified figure only sketches aspects. 
Table 1. Basic interaction values for amorfrutins A, B and 2, and the strong synthetic PPAR $\gamma$ agonist rosiglitazone. Binding affinities to the three PPAR isotypes are expressed as $K_{\mathrm{i}}$ values.

\begin{tabular}{|llcc|} 
Compound & PPAR $\gamma$ & $\begin{array}{c}K_{\mathrm{i}}[\mu \mathrm{M}] \\
\text { PPAR } \alpha\end{array}$ & PPAR $\beta / \delta$ \\
\hline amorfrutin A & 0.236 & 27 & 27 \\
amorfrutin B & 0.019 & 2.6 & 1.8 \\
amorfrutin 2 & 0.287 & 25 & 17 \\
rosiglitazone & 0.007 & n.d. & n.d. \\
\hline n.d.: not determined. Data from refs. [2] and [3].
\end{tabular}

can be influenced by intervening with ligands to fine-tune transcriptional regulation networks. ${ }^{[19]}$ It seems that conventional structure-activity relationship (SAR) analyses of compounds with the LBD of PPAR $\gamma$ do not always make good predictions or allow future outcomes to be straightforwardly optimised. Monitoring of structural dynamics of PPAR $\gamma$ by using amide hydrogen/deuterium exchange kinetics ${ }^{[17]}$ has revealed useful structural and functional information for modelling the effects of ligands.

Alternatively, the potential effects of ligands can be inferred by using a comprehensive structure that comprises a regulatory genomic DNA site and a core transcriptional complex includ-

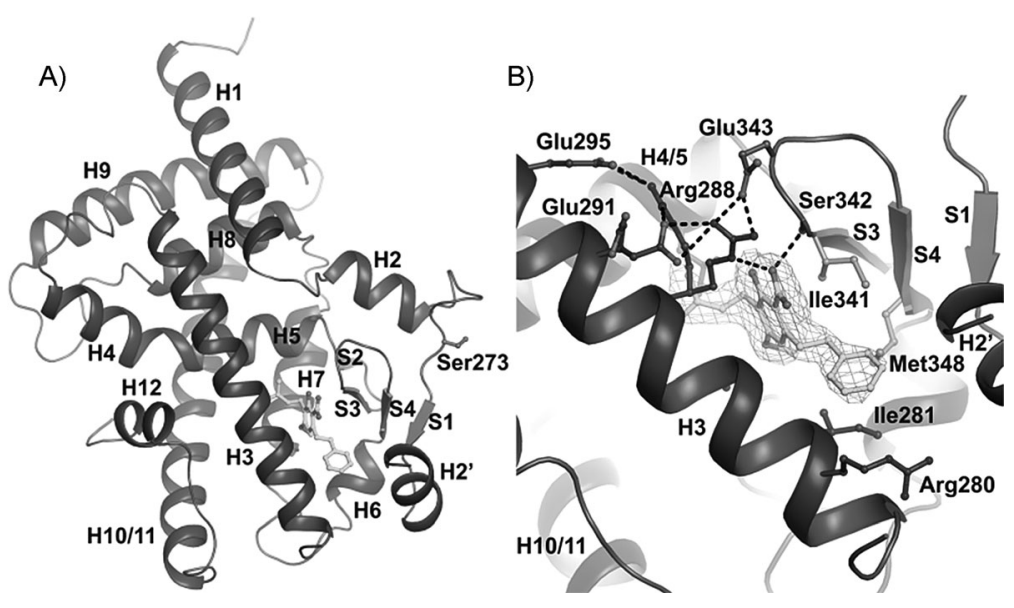

Figure 3. A) X-ray structure of the interaction of amorfrutin A with the ligand binding domain (LBD) of PPAR B) Detail. Reproduced with kind permission from ref. [2]. ing full-length PPAR $\gamma$ and the heterodimer-forming partner RXR $\alpha^{[20]}$ However, for accurate prediction of ligand effects on modulating the cellular activity of PPAR $\gamma$, a modelled structure should additionally include key co-regulating proteins, as explained below.

\section{Mechanism of Amorfrutin-Induced Activation of PPAR $\gamma$}

The ligand-mediated binding of PPAR $\gamma$ to specific sequences (gene loci) is guided by many co-activating or co-repressing

in even stronger binding to PPAR $\gamma\left(K_{\mathrm{i}}=19 \mathrm{nmol} \mathrm{L}^{-1}\right.$ for amorfrutin $B$ versus $K_{\mathrm{i}}=236 \mathrm{nmolL}^{-1}$ for amorfrutin A), thus making amorfrutin $B$ a plant-derived molecule with one of the highest affinities so far reported for PPAR $\gamma \cdot{ }^{[3]}$

Nevertheless, in the case of nuclear receptors, strong binding or high activation effects of a ligand (Table 2), which can be detected by functional (albeit artificial) reporter gene assays, often do not reflect strong effects in terms of endogenous gene expression in a cellular context. This is not surprising, because ligand-based activation of nuclear receptors involves complex mechanisms including various interacting proteins and post-translational modifications. These mechanisms

Table 2. Half maximal effective concentration $\left(E C_{50}\right.$ ) values of the amorfrutins $A, B$ and 2, and rosiglitazone with PPAR $\gamma$ as determined using reporter gene assays, according to refs. [2] and [3]. $I C_{50}$ and efficiencies of compounds for inhibiting in vitro PPAR $\gamma / \mathrm{NCoR}$ binding are shown. The relative activation or inhibition efficiencies of the amorfrutins are relative to rosiglitazone (100\%).

\begin{tabular}{|llccc|} 
Compound & \multicolumn{2}{c}{ PPAR } & \multicolumn{2}{c|}{ PPAR $\gamma / \mathrm{NCoR}$ binding } \\
& $\mathrm{EC}_{50}[\mu \mathrm{M}]$ & $\begin{array}{l}\text { Activation } \\
\text { efficacy [\%] }\end{array}$ & $\mathrm{IC}_{50}[\mu \mathrm{M}]$ & $\begin{array}{l}\text { Inhibition } \\
\text { efficacy [\%] }\end{array}$ \\
\hline amorfrutin A & 0.458 & 39 & 0.051 & 75 \\
amorfrutin B & 0.073 & 25 & 0.060 & 61 \\
amorfrutin 2 & 1.200 & 30 & 0.318 & 85 \\
rosiglitazone & 0.002 & 100 & 0.064 & 100 \\
\hline
\end{tabular}

proteins (Figure 4). In general, in the cell nucleus PPAR $\gamma$ forms a heterodimer with nuclear receptor retinoid $X$ receptor alpha $(\mathrm{RXR} \alpha)$. Ligand-induced modulation of gene expression depends on the conformational change and resulting different interaction of PPAR $\gamma$ with a number of proteins. This compoundbased modulation can lead to the formation of specific complexes of regulatory proteins to control the transcription of genes by RNA polymerase II. ${ }^{[21]}$

For example, depending on the structure of the small molecule ligand, resulting conformational changes of PPAR $\gamma$ can cause differential binding of transcriptional co-activators, such as PPAR $\gamma$ coactivator 1 alpha (PGC-1 $\alpha$ ) and transcriptional intermediary factor 2 (TIF2), or co-repressors, such as nuclear receptor co-repressor 1 (NCoR1) and silencing mediator for retinoid and thyroid-hormone receptor (SMRT; Figure 4). ${ }^{[22]}$ Moreover, post-translational modifications of PPAR $\gamma$ (e.g. phosphorylation) seem to play a key role in establishing and regulating complexes of co-regulating proteins. ${ }^{[23]}$

Importantly, deletion (or inactivation) of NCoR1 in adipocytes of high-fat diet (HFD)-induced diabetic mice resulted in similar gene expression patterns as observed after treatment of wild-type mice with powerful ligands (agonists) of PPAR $\gamma$. $^{[2]}$ NCoR1, a large protein of about 2500 amino acids, strongly interacts with PPAR $\gamma$ and other coregulating proteins, including the kinase CDK5. CDK5, recruited by NCoR1, phosphorylates PPAR $\gamma$ at serine 273, thereby disturbing the expression of 


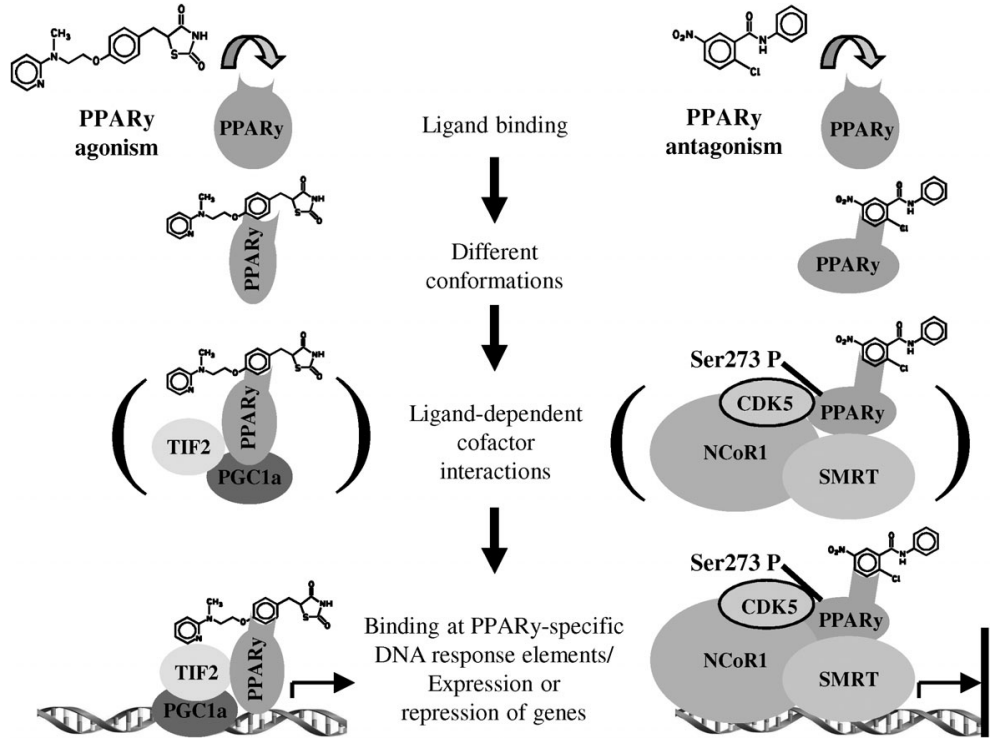

Figure 4. Mechanism of ligand-induced modulation of PPAR $\gamma$ exemplified by agonist (left) and antagonist (right) compounds. Depending on the structure of the compound, protein complexes are built with PPAR $\gamma$ including coactivator (PGC1 $\alpha, \mathrm{TIF} 2)$ or corepressor proteins (NCOR1, SMRT). Such PPAR $\gamma$ complexes interact with more or less sequencespecific sites of the genome, thereby resulting in increased target gene expression through activation of transcription (left) or gene repression (inhibition of transcription initiation, right). Brackets indicate a hypothetical or transitional state.

Interestingly, in adipocytes, but also in MCF7 cells, ${ }^{[2,3,5]}$ amorfrutins decreased efficiently the expression of genes involved in inflammation by interfering with the transcription factor NF- $\kappa B$ pathway. Inflammation can be efficiently triggered by activation of $\mathrm{NF}-\kappa \mathrm{B}$. We recently observed in adipocytes ${ }^{[2,3]}$ that the anti-inflammatory effects of amorfrutins $A$ and $B$ can at least partly be explained by activation of PPAR $\gamma$. Ligand-activated PPAR $\gamma$ competes (in part) with NF-KB for binding at a number of genomic sites (Figure 2), ${ }^{\left[{ }^{0]}\right]}$ thereby at least weakly repressing the expression of inflammatory mediators (other alternative mechanisms are briefly described in the legend of Figure 2). Notably, chronic mild inflammation in adipose tissue can cause insulin resistance. ${ }^{[31]}$ Thus, the amorfrutin-induced down-regulation of inflammatory mediator genes in adipocytes might additionally explain some of the observed antidiabetic effects. ${ }^{[2,3,6,10 a]}$

Moreover, the known interference of PPAR $\gamma$ with inflammatory disorders, cancer and age-related disease $^{[32]}$ suggests further potential fields of application of the amorfrutins. For example, in our laboratory we discovered subsets of amorfrutins with the potential for inhibiting inflammation mediated by tumour necrosis factor alpha (TNF $\alpha$ ) in HT-29 colon

many metabolic target genes (Figure 4). ${ }^{[23-25]}$ Consequently, knock-down of the central regulatory protein NCoR1 in adipose tissue increased significantly insulin sensitivity in dietinduced obese mice. ${ }^{[24]}$

As a general concept, it seems that selective PPAR $\gamma$ agonists such as the amorfrutins exert their specific insulin sensitising effects in particular through inhibition of the interaction of the repressor NCoR1 with PPAR $\gamma$, as indicated by in vitro co-repressor assays (Table 2). ${ }^{[2,3]}$ Specific utilisation of this selective activation mechanism holds promise for further development. In line with the concept of selective activation of PPAR $\gamma$, genome-wide expression analyses of various amorfrutin treatments in adipocytes showed overall promising gene expression profiles. ${ }^{[2,3]}$ These profiles indicated partial activation of PPAR $\gamma$ known from selective agonists such as telmisartan ${ }^{[26]}$ and other synthetic molecules. ${ }^{[2,3]}$

Amongst others, amorfrutins $A$ and 2 significantly up-regulated metabolic pathways such as PPAR signalling and mitochondrial fatty acid betaoxidation, whereas inflammatory response pathways including Toll-like receptor signalling and cytokine-cytokine receptor interactions were down-regulated. ${ }^{[2]}$ Furthermore, application of the connectivity map approach $^{[27]}$-a pattern-matching method to discover potential functional connections between drugs, genes and diseases through gene expression profiles-indicated that amorfrutins act as (PPAR $\gamma$-regulating) insulin sensitizers. However, such natural products can also, at least weakly, interfere with other cellular proteins. ${ }^{[28]}$ On the other hand, such interferences might have synergistic effects, as known for a long time for polypharmacological products. ${ }^{[14,29]}$ cells (Fuhr et al., unpublished results). These anti-inflammatory effects were partly dependent on activation of PPAR $\gamma$ resulting in repression of a number of inflammation marker genes and chemokines. And, because of their structural similarities with salicylates, amorfrutins might additionally share cyclooxygenases as protein targets to inhibit inflammatory response. This hypothesis has not yet been tested and will require study soon.

Other subsets of multiply prenylated amorfrutins efficiently killed colon and other cancer cells through so-far unknown mechanisms (C. Weidner et al., unpublished results). In general, multiply prenylated natural products are known for their potent anticarcinogenic profiles. ${ }^{[33]}$ This might argue for investigating in more depth the potential of multiply prenylated amorfrutins (prenylated moieties $R^{1}$ and $R^{4}$, Figure 1C) for treating cancer. Clearly, these promising observations need further exploration, in particular to gain mechanistic understanding.

\section{In Vivo Effects of Amorfrutins}

A number of synthetic molecules have been developed to activate PPAR $\gamma$ for treating type 2 diabetes. ${ }^{[34]}$ The strong synthetic PPAR $\gamma$ agonists of the thiazolidinedione class, including the widely applied drugs rosiglitazone (Avandia) and pioglitazone (Actos), have been developed to efficiently reduce glucose levels in type 2 diabetes patients. Unfortunately these compounds were found to be associated with adverse effects such as fluid retention, cardiovascular complications, bladder cancer, bone resorption and weight gain. ${ }^{[35]}$ These side effects are attributed to unspecific activation of various molecular processes and to still poorly understood off-target effects. ${ }^{[36]}$ Over the 
past years, a number of structurally diverse, selective PPAR $\gamma$ modulators (SPPAR $\gamma \mathrm{Ms}$ ) have been optimised for treating type 2 diabetes with less side effects. ${ }^{[37]}$ Many of these molecules were clinically tested including phase II and III trials but so far without success.

Compared to the synthetic ligands of PPAR $\gamma$ the natural amorfrutins exhibit diverse chemical structures and properties. A panel of ADMET (absorption, distribution, metabolism, excretion and toxicity) and pharmacokinetic and physiological studies in mice suggested that amorfrutins $A, B$ and 2 are safe compounds and that they are sufficiently distributed but rapidly metabolically transformed and excreted in vivo after several hours. ${ }^{[2,3]}$ As we reported in these studies, in insulin-resistant, diet-induced obese and in genetic diabetes mouse models, amorfrutin treatment strongly increased insulin sensitivity and glucose tolerance and improved many other physiological parameters (Table 3). Strikingly, early intervention with amorfru-

Table 3. Conventional checks for preclinical testing of PPAR $\gamma$-based antidiabetic compounds such as amorfrutins.

Key issues for evaluating PPAR $\gamma$-activating and potentially antidiabetic compounds in model organisms such as insulin-resistant obese mice (see refs. [2] and [3]).

- weight development

- tissues (e.g., adipose tissue, liver, muscle, pancreas)-morphology and tissue-specific biological marker based assays

- fasting glucose and fasting insulin levels

- oral glucose tolerance test (OGGT)

- intraperitoneal insulin sensitivity test (IPIST)

- homeostatic model assessment of insulin resistance (HOMA-IR)

- lipid profiles (triglycerides, free fatty acids, cholesterol)

- hormones beyond insulin: leptin, thyroxin derivatives, adiponectin, etc.

- inflammation markers such as TNF $\alpha$

- known side effects of PPAR $\gamma$-activating diabetes drugs

(thiazolidinediones)

tins inhibited the development of fatty liver during high-fat diet treatment of mice, an exciting feature to prevent metabolic liver diseases; mechanistic studies are required to gain insights into this striking phenomenon. ${ }^{[2,3]}$ Interestingly, in various diabetic mouse models, amorfrutins did not show the unwanted side effects of the thiazolidinediones, in part likely because of their selective activating of PPAR $\gamma$. Clearly, more indepth and long-term evaluation of treatment with amorfrutins is important for preclinical and clinical testing.

\section{Biosynthesis and Chemical Synthesis of Amorfrutins}

The biosynthetic pathway of amorfrutins in plants has not been studied in great detail. At first sight, it seems plausible that amorfrutins share biosynthesis pathways with related natural products, such as salicylates and prenylated natural products. ${ }^{[33]}$ The pathways of these compounds include the aromatic synthesis routes (including the shikimate and acetate/malonate pathways) and the isoprenoid routes, such as mevalonate pathway (in the cytosol) and methyl erythritol phosphate pathways (in the plastid). ${ }^{[33]}$

The biosynthesis of bibenzyl amorfrutin derivatives involves type III polyketide synthases. ${ }^{[38]}$ For the synthesis of bibenzyl amorfrutins such as amorfrutin A, stilbene carboxylate synthases (STCSs) ${ }^{[39]}$ were considered key enzymes. STCSs produce resorcylic acid moieties from tetraketide free acid, as well as additional aromitisation and reduction reactions ${ }^{[40]}$ to build a basic structure for further biosynthesis to generate amorfrutin $\mathrm{A}$ and many other products (Scheme $1 \mathrm{~A}$ ). In general, prenylated aromatic compounds are produced by specific, mostly membrane-bound prenyltransferases. ${ }^{[33]}$ Future knowledge on the exact biosynthesis pathways of amorfrutins might help to develop efficient biotechnological strategies to synthesise amorfrutins in higher amounts in heterologous systems, either by metabolic engineering in suitable plants or by biotransformation of microbial species.

In the last two years, various chemical strategies have been reported for the synthesis of amorfrutins. Prenyl bibenzyl derivatives are commonly produced by Wittig reaction and subsequent alkene hydrogenation. ${ }^{[41]}$ However, prenyl bibenzyl amorfrutins contain a 6-alkyl-2,4-dihydroxybenzoic acid (or resorcylic acid) unit. Based on the above biosynthesis based on catalysis by STCSs, Laclef et al. recently published a five step chemical synthesis route of amorfrutin $A^{[42 a]}$ This biomimetic procedure starts from dioxinone, and includes acylation with benzotriazole and palladium-catalysed decarboxylative prenylation (Scheme 1B). ${ }^{[42]} \mathrm{A}$ further interesting feature of this procedure was the regioselective decarboxylative prenyl migration and generation of an recorcylate after forced $\mathrm{Pd}\left(\mathrm{PPh}_{3}\right)_{4}$ and caesium carbonate treatment as described in detail by Laclef et al. ${ }^{[42 a]}$ The authors achieved an overall yield of $16 \%$.

To avoid problems associated with purifying Wittig salts derived from conventional methods to synthesise bibenzyl derivatives, Frank Schroeder and co-workers introduced a triflate as precursor for the multigram synthesis of amorfrutins, ${ }^{[2]}$ by using 2,4,6-trihydroxybenzoic acid as starting material and applying a procedure of Kamisuki et al. ${ }^{[43]}$ (Scheme $2 \mathrm{~A}$ ).

Sonogashira coupling was performed to introduce aromatic or other side chains. ${ }^{[2]}$ For the introduction of prenyl side chains, a number of conditions were fine-tuned to avoid potential prenylation at position 5 or O-prenylation at the hydroxy group. The prenylation step was the most delicate step of the entire procedure. In the optimised case, an overall yield of $35 \%$ was reported for this proposed synthesis route. As an alternative, Song et al. suggested a six-step synthesis procedure based on tandem Michael addition, intramolecular Claisen condensation and oxidative aromatisation (Scheme 2B). ${ }^{[4]}$ Whereas the first part of their synthesis was unique, the second prenylation step was in principle similar to the method of Schroeder et al. The facile reaction sequence of Song et al. achieved an overall yield of $27 \%$ for the synthesis of amorfrutin A.

The various published synthesis routes might help optimise efficient compound synthesis, as well as the identification of potential off-targets by adding functionalities to the amorfrutins for isolating and identifying bound proteins by mass spec- 
A) Flores-Sanchez et al.

B)

Laclef et al.

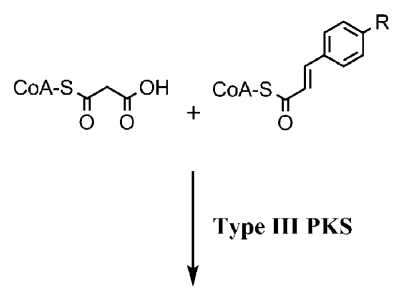<smiles>[R]c1ccc(C=CC(=O)CC(=O)CC(=O)OS(C)(C)C)cc1</smiles>

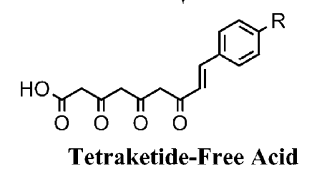<smiles>[R]c1ccc(C=C(Cc2cc(O)cc(O)c2)C(=O)O)cc1</smiles>

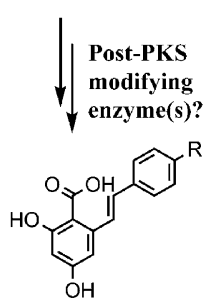

A Stilbene Acid
Post-PKS modifying enzyme(s)?

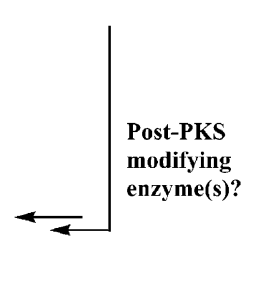<smiles>O=C(Cl)CC1=CC=[C+]C=C1</smiles><smiles>CC1=C(C)C(C)(O)OC1=O</smiles>

Acylation $\downarrow$ Acyl

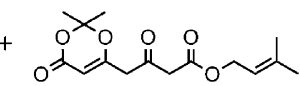
Regioselective acylation $\downarrow$ Claisen condensation<smiles>CC(C)=COC(=O)C(CC1=CC(=O)OC1(C)C)C(=O)C(=O)CCc1ccccc1</smiles>

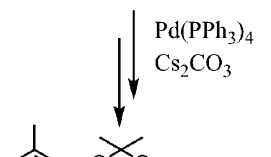<smiles>COC(=O)c1c(CC=C(C)C)c(O)cc(CCc2ccccc2)c1OC(C)(C)C</smiles><smiles>COc1cc(CCc2ccccc2)c(C(=O)OC(C)(C)C)c(CC=C(C)C)c1OC</smiles><smiles>CC=CCOc1c(CC(C)C)c(OC)cc(Cc2ccccc2)c1C(=O)O</smiles>

Amorfrutin A

Scheme 1. A) As reviewed in ref. [38], biosynthesis of bibenzyl derivatives based on cyclisation catalysed by type III plant polyketides (PKSs). Stilbene carboxylate synthases (STCSs) produce tetraketide-free acids that are converted by further enzymes to a stilbene acid. Alternatively, tetraketide lactones can be produced by coumaroyl triacetic acid synthases (CTASs), thereby resulting through additional steps in stilbene acids. B) Biomimetic synthesis of amorfrutin $\mathrm{A}$ by using a palladium-catalysed prenylation-aromitisation procedure according to [42a].

(or alternatively an additional PPAR-activating ${ }^{[14]}$ compound) background, might support appropriate activation of PPAR $\gamma$, especially to inhibit the early development of disorders such as insulin resistance. Synergistic physiological effects might be achieved by combining amorfrutins with natural products that target proteins other than PPAR $\gamma$, such as anti-inflammatory salicylates from willow bark or green tea ingredients, such as epigallocatechine gallate derivatives.

Clearly, before broad application of such nutraceutical or phytomedical products, a number of regulatory issues will have to be clarified. Importantly, new efficient methods for early diagnosis and monitoring treatments of complex diseases are very sought-after to establish and support validated prevention approaches. ${ }^{[6,46]}$ Without doubt, prevention strategies based on molecular insights and rational optimisation might eventually help the ageing population to cope with age-related diseases, such as type 2 diabetes. Furthermore, such approaches might significantly reduce the increasing burden on healthcare systems and society. On the other hand, substantial implementation of preventive medicine would imply overturning major research paradigms, and estab-

trometry. ${ }^{[45]}$ In general, as they have a rather simple core structure, amorfrutins offer many possibilities for pharmacological optimisation.

\section{Preventive Application of the Amorfrutins}

As they are produced by edible plants, amorfrutins can be used for developing functional food or nutraceuticals with substantially proven medical effects, for rationally preventing or treating physiological disorders.

Interestingly, without provoking adverse effects, human physiology induces strong activation peaks of PPAR $\gamma$ and metabolic gene expression, every day after each meal. Consequently food products or a phytomedical extract could be enriched with safe liquorice extracts containing sufficient amounts of amorfrutins. Such products with a noninterfering lished procedures in disease management and economics. Accumulating scientific evidence will hopefully accelerate this trend and break barriers in the coming decades.

\section{Conclusion and Outlook}

A growing body of evidence suggests that targeted behavioural or nutritional intervention at early stages can impede the development of major metabolic diseases and potentially other complex diseases. ${ }^{[47]}$ Molecular prevention strategies based on solid scientific evidence might complement or even largely replace established but at least partly unsatisfactory treatment approaches for counteracting complex diseases such as type 2 diabetes.

Gene-regulating nuclear receptors such as PPAR $\gamma$ and chromatin-modifying epigenetic enzymes like the histone deacety- 
A) Schroeder et al.<smiles>O=C(O)c1c(O)cc(O)cc1O</smiles><smiles>COc1cc(O)c(OC)c2c1OC(C)(C)O2</smiles><smiles></smiles>

$\mathrm{OCH}_{3}$ $\mathrm{H}_{2} / \mathrm{Pd}(\mathrm{OH})_{2}$<smiles>COc1cc(CCc2ccccc2)c(OC)c(OC)c1</smiles>
$\mathrm{CH}_{3} \mathrm{OLi} / \mathrm{MeOH}$<smiles>COc1cc(O)c(CCc2ccccc2)c(OC)c1</smiles>

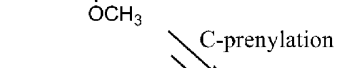

\section{C-prenylation}

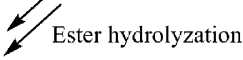

Ester hydrolyzation

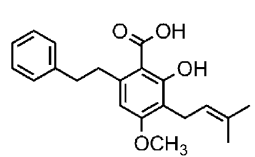

Amorfrutin A

Scheme 2. Two alternative synthesis procedures using either A) 2,4,6-trihydroxybenzoic acid, according to refs. [2] and Kamisuki et al. (ref. [43]), or B) phenylpropyl aldehyde, according to ref. [44], as starting material, resulting in 2-hydroxy-4-methoxy-6-phenethylbenzoic acid methyl/ethyl ester. Regioselective C-prenylation and ester hydrolysis were performed under similar conditions.

lases ${ }^{[48]}$ are interesting targets in health application. Both protein classes are key factors for daily regulation and maintenance of overall homeostasis. Compounds such as the amorfrutins are particularly attractive for maintaining homeostasis because of their potential to selectively fine-tune the action of genes through selective activation of PPAR $\gamma$. As dietary molecules, amorfrutins offer great potential for evidence-based application as functional food or nutraceuticals, ${ }^{[49]}$ in addition to serving as ingredients for phytomedical products and lead structures for pharmaceutical development. ${ }^{[50]}$

This concise review aims to summarise the current knowledge on amorfrutins and to provoke further research. In-depth studies and innovative developments will be needed to explore the promising potential of the amorfrutins to efficiently prevent and treat metabolic (and possibly other complex) diseases.

\section{Acknowledgements}

Our work on the amorfrutins was a team effort of many excellent colleagues who can unfortunately not all be mentioned here. I would in particular like to thank Konrad Büssow for supporting our screening projects and for structural analyses, Karsten Siems for fruitful discussions, Magdalena Kliem for the discovery of amorfrutins as binders of PPAR $\gamma$ and help with this review, Frank C. Schroeder for the synthetic amorfrutins and for correcting parts of an early version of the review, and Christopher Weidner for important comprehensive contributions to the in vitro and in vivo studies. I thank Sophia Bauch for preparing the schemes. Our work has been funded by the German Ministry for Education and Research (BMBF, grant numbers 0315082, 01EA1303), the National Genome Research Net (NGFN, grant number 01 GS 0828), and the European Union (FP7/2007-2013, under grant agreement no. 262055 (ESGI)).

Keywords: gene expression - ligand effects - metabolic diseases $\cdot$ nutraceuticals $\cdot$ receptors

[1] L. A. Mitscher, Y. H. Park, A. Alshamma, P. B. Hudson, T. Haas, Phytochemistry 1981, 20, $781-785$.

[2] C. Weidner, J. C. de Groot, A. Prasad, A. Freiwald, C. Quedenau, M Kliem, A. Witzke, V. Kodelja, C.-T. Han, S. Giegold, M. Baumann, B. Klebl, K. Siems, L. Müller-Kuhrt, A. Schürmann, R. Schüler, A. F. H. Pfeiffer, F. C. Schroeder, K. Büssow, S. Sauer, Proc. Natl. Acad. Sci. USA 2012, 109, $7257-7262$.

[3] C. Weidner, S. J. Wowro, A. Freiwald, K. Kawamoto, A. Witzke, M. Kliem, K. Siems, L. Müller-Kuhrt, F. C. Schroeder, S. Sauer, Diabetologia 2013 $56,1802-1812$

[4] J. Bellakhdar, La pharmacopée marocaine traditionnelle: Médecine arabe ancienne et savoirs populaires, Ibis, Paris, 1997.

[5] N. T. Dat, J.-H. Lee, K. Lee, Y.-S. Hong, Y. H. Kim, J. J. Lee, J. Nat. Prod. 2008, 71, 1696-1700.

[6] D. Meierhofer, C. Weidner, L. Hartmann, J.A. Mayr, C.-T. Han, F. C. Schroeder, S. Sauer, Mol. Cell. Proteomics 2013, 12, 1965-1979.

[7] D. J. Mangelsdorf, C. Thummel, M. Beato, P. Herrlich, G. Schütz, K. Umesono, B. Blumberg, P. Kastner, M. Mark, P. Chambon, R. M. Evans, Cell $1995,83,835-839$.

[8] R. M. Evans, G. D. Barish, Y.-X. Wang, Nat. Med. 2004, 10, 355-361.

[9] B. M. Spiegelman, Diabetes 1998, 47, 507-514.

[10] a) S. J. Bensinger, P. Tontonoz, Nature 2008, 454, 470-477; b) L. Dubuquoy, C. Rousseaux, X. Thuru, L. Peyrin-Biroulet, O. Romano, P. Chavatte M. Chamaillard, P. Desreumaux, Gut 2006, 55, 1341-1349; c) J. M. Peters, Y. M. Shah, F. J. Gonzalez, Nat. Rev. Cancer 2012, 12, 181 - 195.

[11] M. G. Myers Jr., C. F. Burant, Nat. Med. 2011, 17, 544-545.

[12] G. Rizzo, S. Fiorucci, Curr. Opin. Pharmacol. 2006, 6, 421-427.

[13] a) R. T. Nolte, G. B. Wisely, S. Westin, J. E. Cobb, M. H. Lambert, R. Kurokawa, M. G. Rosenfeld, T. M. Willson, C. K. Glass, M. V. Milburn, Nature 1998, 395, 137-143; b) S. A. Kliewer, J. M. Lenhard, T. M. Willson, I. Patel, D. C. Morris, J. M. Lehmann, Cell 1995, 83, 813-819.

[14] a) C. Weidner, S. J. Wowro, M. Rousseau, A. Freiwald, V. Kodelja, H. Abdel-Aziz, O. Kelber, S. Sauer, PLoS One 2013, 8, e80335; b) C. Weidner S. J. Wowro, A. Freiwald, V. Kodelja, H. Abdel-Aziz, O. Kelber, S. Sauer, Mol. Nutr. Food Res. 2014, 58, 903-907.

[15] J. C. de Groot, C. Weidner, J. Krausze, K. Kawamoto, F. C. Schroeder, S. Sauer, K. Büssow, J. Med. Chem. 2013, 56, 1535-1543.

[16] D. R. Artis, J. J. Lin, C. Zhang, W. Wang, U. Mehra, M. Perreault, D. Erbe H. I. Krupka, B. P. England, J. Arnold, A. N. Plotnikov, A. Marimuthu, H. Nguyen, S. Will, M. Signaevsky, J. Kral, J. Cantwell, C. Settachatgull, D. S. Yan, D. Fong, et al., Proc. Natl. Acad. Sci. USA 2009, 106, 262-267.

[17] J. B. Bruning, M. J. Chalmers, S. Prasad, S. A. Busby, T. M. Kamenecka, Y. He, K. W. Nettles, P. R. Griffin, Structure 2007, 15, 1258-1271. 
[18] a) T. Kim, W. Lee, K. H. Jeong, J. H. Song, S.-H. Park, P. Choi, S.-N. Kim, S Lee, J. Ham, Bioorg. Med. Chem. Lett. 2012, 22, 4122-4126; b) L. A Mitscher, S. R. Gollapudi, S. Drake, D. S. Oburn, Phytochemistry 1985, 24, $1481-1483$

[19] a) R. Feldmann, A. Geikowski, C. Weidner, A. Witzke, V. Kodelja, T. Schwarz, M. Gabriel, T. Erker, S. Sauer, PLoS One 2013, 8, e57311; b) R. Feldmann, C. Fischer, V. Kodelja, S. Behrens, S. Haas, M. Vingron, B. Timmermann, A. Geikowski, S. Sauer, Nucleic Acids Res. 2013, 41, 3518 3531.

[20] V. Chandra, P. Huang, Y. Hamuro, S. Raghuram, Y. J. Wang, T. P. Burris, F. Rastinejad, Nature 2008, 456, 350-356.

[21] a) H. Gronemeyer, J.-A. Gustafsson, V. Laudet, Nat. Rev. Drug Discovery 2004, 3, 950-964; b) L. Nagy, J. W. Schwabe, Trends Biochem. Sci. 2004 29, 317-324.

[22] A. Mottis, L. Mouchiroud, J. Auwerx, Genes Dev. 2013, 27, 819-835.

[23] J. H. Choi, A. S. Banks, J. L. Estall, S. Kajimura, P. Boström, D. Laznik, J. L. Ruas, M. J. Chalmers, T. M. Kamenecka, M. Blüher, P. R. Griffin, B. M. Spiegelman, Nature 2010, 466, 451-456.

[24] P. Li, W. Fan, J. Xu, M. Lu, H. Yamamoto, J. Auwerx, D. D. Sears, S. Talukdar, D. Oh, A. Chen, G. Bandyopadhyay, M. Scadeng, J. M. Ofrecio, S. Nalbandian, J. M. Olefsky, Cell 2011, 147, 815-826.

[25] B. B. Kahn, T. E. McGraw, N. Engl. J. Med. 2010, 363, 2667-2669.

[26] M. Schupp, M. Clemenz, R. Gineste, H. Witt, J. Janke, S. Helleboid, N. Hennuyer, P. Ruiz, T. Unger, B. Staels, U. Kintscher, Diabetes 2005, 54 $3442-3452$.

[27] J. Lamb, E. D. Crawford, D. Peck, J. W. Modell, I. C. Blat, M. J. Wrobel, J. Lerner, J.-P. Brunet, A. Subramanian, K. N. Ross, M. Reich, H. Hieronymus, G. Wei, S. A. Armstrong, S. J. Haggarty, P. A. Clemons, R. Wei, S. A. Carr E. S. Lander, T. R. Golub, Science 2006, 313, 1929-1935.

[28] a) S. Wetzel, R. S. Bon, K. Kumar, H. Waldmann, Angew. Chem. Int. Ed. 2011, 50, 10800-10826; Angew. Chem. 2011, 123, 10990-11018; b) S. Quideau, D. Deffieux, C. Douat-Casassus, L. Pouységu, Angew. Chem. Int. Ed. 2011, 50, 586-621; Angew. Chem. 2011, 123, 610-646.

[29] H. Wagner, Fitoterapia 2011, 82, 34-37.

[30] a) M. I. Lefterova, Y. Zhang, D. J. Steger, M. Schupp, J. Schug, A. Cristancho, D. Feng, D. Zhuo, C. J. Stoeckert Jr., X. S. Liu, M. A. Lazar, Genes Dev. 2008, 22, 2941-2952; b) M. S. Hamza, S. Pott, V. B. Vega, J.S Thomsen, G. S. Kandhadayar, P. W. P. Ng, K. P. Chiu, S. Pettersson, C. L. Wei, Y. Ruan, E. T. Liu, PLoS One 2009, 4, e4907.

[31] a) M. F. Gregor, G. S. Hotamisligil, Annu. Rev. Immunol. 2011, 29, $415-$ 445 ; b) A. Freiwald, C. Weidner, A. Witzke, S.-Y. Huang, D. Meierhofer, S Sauer, Proteomics 2013, 13, 3424-3428.

[32] M. J. Khandekar, P. Cohen, B. M. Spiegelman, Nat. Rev. Cancer 2011, 11, $886-895$.
[33] K. Yazaki, K. Sasaki, Y. Tsurumaru, Phytochemistry 2009, 70, 1739-1745.

[34] P. Gervois, J.-C. Fruchart, B. Staels, Nat. Clin. Pract. Endocrinol. Metab. 2007, 3, 145-156.

[35] R. H. Houtkooper, J. Auwerx, Nature 2010, 466, 443-444.

[36] D. Jones, Nat. Rev. Drug Discovery 2010, 9, 668-669.

[37] B. Pourcet, J.-C. Fruchart, B. Staels, C. Glineur, Expert Opin. Emerging Drugs 2006, 11, 379-401.

[38] I. J. Flores-Sanchez, R. Verpoorte, Plant Physiol. Biochem. 2009, 47, $167-$ 174.

[39] C. Eckermann, G. Schröder, S. Eckermann, D. Strack, J. Schmidt, B. Schneider, J. Schröder, Phytochemistry 2003, 62, 271-286.

[40] T. Akiyama, M. Shibuya, H.-M. Liu, Y. Ebizuka, Eur. J. Biochem. 1999, 263, $834-839$

[41] L. Crombie, S. V. Jamieson, J. Chem. Soc. Perkin Trans. 1 1982, $1467-$ 1475.

[42] a) S. Laclef, K. Anderson, A. J. P. White, A. G. M. Barrett, Tetrahedron Lett. 2012, 53, 225-227; b) K. Anderson, F. Calo, T. Pfaffeneder, A. J. P. White A. G. M. Barrett, Org. Lett. 2011, 13, 5748-5750.

[43] S. Kamisuki, S. Takahashi, Y. Mizushina, S. Hanashima, K. Kuramochi, S. Kobayashi, K. Sakaguchi, T. Nakata, F. Sugawara, Tetrahedron 2004, 60, $5695-5700$

[44] Y. Y. Song, H. G. He, Y. Li, Y. Deng, Tetrahedron Lett. 2013, 54, 2658 2660

[45] S. Ziegler, V. Pries, C. Hedberg, H. Waldmann, Angew. Chem. Int. Ed. 2013, 52, 2744-2792; Angew. Chem. 2013, 125, 2808-2859.

[46] a) M. Ezzati, E. Riboli, Science 2012, 337, 1482-1487; b) S. Sauer, Expert Rev. Proteomics 2013, 10, 305-307.

[47] a) M. H. T. Wong, C. Holst, A. Astrup, T. Handjieva-Darlenska, S. A. Jebb, A. Kafatos, M. Kunesova, T. M. Larsen, J. A. Martinez, A. F. H. Pfeiffer, M. A. van Baak, W. H. M. Saris, P. D. McNicholas, D. M. Mutch, PLoS One 2012, 7, e42858; b) T. M. Larsen, S.-M. Dalskov, M. van Baak, S. A. Jebb A. Papadaki, A. F. H. Pfeiffer, J. A. Martinez, T. Handjieva-Darlenska, M Kunešová, M. Pihlsgård, S. Stender, C. Holst, W. H. M. Saris, A. Astrup, N. Engl. J. Med. 2010, 363, 2102-2113.

[48] S. Holzhauser, A. Freiwald, C. Weise, G. Multhaup, C.-T. Han, S. Sauer, Angew. Chem. Int. Ed. 2013, 52, 5171-5174; Angew. Chem. 2013, 125, $5277-5281$

[49] M. Müller, S. Kersten, Nat. Rev. Genet. 2003, 4, 315-322.

[50] K. Kumar, H. Waldmann, Angew. Chem. Int. Ed. 2009, 48, 3224-3242; Angew. Chem. 2009, 121, 3272-3290.

[51] Y. Hou, F. Moreau, K. Chadee, Nat. Commun. 2012, 3, 1300.

Received: March 25, 2014 